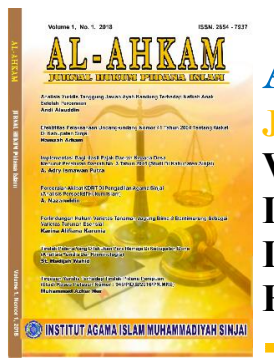

\title{
IMPLEMENTASI SISTEM PERADILAN PIDANA PADA ANAK DI KABUPATEN SINJAI
}

\author{
Andi Alauddin', Fadly ${ }^{2}$, Muhammad Azhar Nur ${ }^{3}$ \\ ${ }^{1}$ Institut Agama Islam Muhammadiyah Sinjai, Jl.Sultan Hasanuddin No.20, Kabupaten Sinjai \\ ${ }^{2}$ Institut Agama Islam Muhammadiyah Sinjai, Jl.Sultan Hasanuddin No.20, Kabupaten Sinjai \\ ${ }^{3}$ Institut Agama Islam Muhammadiyah Sinjai, Jl.Sultan Hasanuddin No.20, Kabupaten Sinjai \\ E-mail: andialauddin07@gmail.com Tlp:085242614913
}

\begin{abstract}
Abstrak
Penelitian ini bertujuan Untuk mengetahui implementasi Putusan Nomor Perkara 2/Pen.Div/2020 Pengadilan Negeri Sinjai terhadap proses perkara anak sebagai pelaku tindak pidana dan Untuk mengetahi dampak Putusan Pengadilan Negeri Sinjai terhadap anak nakal yang sementara menjalani putusan pengadilan. Adapun metode yang digunakan dalam peneltian ini penulis menggunakan metode pendekatan Empiris yang dilaksanakan pada tahun 2020 berlokasi di kabupaten Sinjai Provinsi Sulawesi Selatan. Hasil yang diperoleh dalam penelitian ini yaitu Perlindungan hukum terhadap anak dalam proses peradilan dilakukan dimulai semenjak tingkat penyelidikan, penyidikan, penuntutan, pemeriksaan di sidang pengadilan sampai pada pelaksanaan putusan pengadilan. Pertimbangan di atas menjadi alasan hakim memberikan penetapan, bahwa kesepakatan diversi tersebut telah memenuhi dan tidak bertentangan dengan hukum, agama, kepatuhan masyarakat setempat, kesusilaan atau memuat hal-hal yang tidak dapat dilaksanakan anak, dan telah memuat etika baik, sehingga beralasan untuk dikabulkan. Seringkali anak yang berhadapan dengan hokum menerima perlakuan buruk dari masyarakat sehingga akan memepengaruhi kondisi kejiwaan anak. Segala tindakan yang dilakukan seorang anak karena kemauannya, tidak dilandasi oleh faktor tunggal terjadinya kejahatan, namun karena adanya factor lain yang melatar belakangi, diantaranya kondisi lingkungan, ekonomi, dll. Hal tersebut menjadikan anak sebagai pelaku kejahatan berada dalam posisi sebagai korban.
\end{abstract}

Kata Kunci: Anak, Hukum, Peradilan Pidana

\begin{abstract}
This study aims to determine the implementation of the Decision Case Number $2 /$ Pen.Div / 2020 Sinjai District Court on the process of cases of children as perpetrators of criminal offenses and to find out the impact of the Sinjai District Court Decisions on delinquents who are currently undergoing court decisions. The method used in this research is the author uses the Empirical approach method which was implemented in 2020 located in Sinjai district, South Sulawesi Province. The results obtained in this study are legal protection for children in the judicial process starting from the level of investigation, investigation, prosecution, examination in court to the implementation of court decisions. The above considerations are the reasons for the judge to determine that the diversion agreement has fulfilled and does not conflict with law, religion, local community obedience, morals or contains things that cannot be carried out by children, and contains good ethics, so that it is reasonable to grant it. Often children who are faced with the law receive bad treatment from the community so that it will affect the child's
\end{abstract}




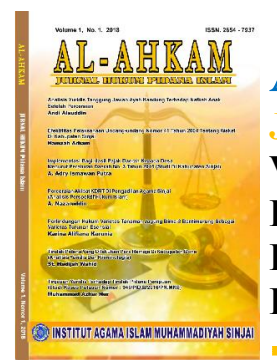

psychological condition. All actions taken by a child because of his will, are not based on a single factor in the occurrence of crime, but because of other factors, including environmental, economic conditions, etc. This puts children as perpetrators of crime in the position of victims.

Keywords: Children, Law, Criminal Justice.

\section{Pendahuluan}

Perkembangan pembangunan perekonomian tidak lepas dari peran serta masyarakat dalam usahanya untuk berpartisipasi dalam pembangunan yang memerlukan situasi dan kondisi yang aman dan tertib. Usaha mewujudkan keamanan dan ketentraman bagi masyarakat, pemerintah telah melaksanakan usaha penanggulangan terhadap setiap gangguan keamanan, baik yang bersifat pencegahan atau preventif maupun dengan penindakan atau represif menindak tegas setiap anggota masyarakat yang melakukan gangguan keamanan atau tindak pidana.

Anak merupakan bagian dari generasi muda sebagai salah satu sumber daya manusia yang merupakan potensi dan penerus cita-cita bangsa yang memiliki peranan strategis dan mempunyai ciri serta sifat khusus yang memerlukan pembinaan dan perlindungan dalam rangka menjamin pertumbuhan dan perkembangan fisik, mental, dan sosial secara utuh, selaras serasi dan seimbang.

Kenakalan anak dapat disebabkan karena pengaruh lingkungan, terutama lingkungan diluar rumah, jika pengaruh lingkungan tidak baik maka anak pasti terpengaruh oleh lingkungan tersebut, karena itu diperlukan peran dan tanggung jawab orang tua terhadap anak, terutama dalam membimbing dan mengarahkan anak untuk melakukan perbuatan yang baik.

Dampak negatif dari pembangunan yang cepat dan arus globalisasi yang pesat telah mempengaruhi perilaku anak. Anak yang melakukan tindak pidana harus berhadapan dengan aparat hukum untuk mempertanggung jawabkan perbuatannya.

Hukum pidana anak meliputi segala aktivitas pemeriksaan dan pemutusan perkara yang menyangkut kepentingan anak. Menurut analisis sejarah (Eropa dan Amerika) bahwa turut campurnya pengadilan dalam kehidupan anak dan keluarga, senantiasa ditujukan untuk menanggulangi keadaaan yang buruk, seperti :

- Kriminalisasi terhadap anak

- Penelantaran

- Eksploitasi anak

- dll

Ketentuan hukum khusus tentang anak yang melakukan tindak pidana diatur dalam Undang-Undang Nomor 11 Tahun 2012 Tentang Sistem Peradilan Pidana Anak pengganti terhadap Undang-Undang Nomor 3 Tahun 1997 tentang Peradilan Anak. Perbedaan perlakuannya terletak pada hokum acara dan ancaman pidananya. Perbedaan tersebut lebih ditujukan untuk memnerikan perlindungan dan pengayoman terhadap anak dalam menyonsong masa depan yang masih panjang, serta memberi kesempatan kepada anak agar setelah melalui pembinaan akan memperoleh jati dirinya untuk menjadi manusia yang mandiri, bertanggung jawab, dan berguna bagi diri, keluarga, masyarakat, bangsa dan negara.

Anak merupakan salah satu korban yang rentan atas pelanggaran hak asasi manusia, yang wajib untuk dilindungi dan dijaga kehormatan, martabat, dan harga dirinya secara wajar baik menurut hukum, ekonomi, politik, sosial dan budaya, tanpa membedakan suku, agama, ras, dan golongan. Hak-hak anak melekat di dalam diri anak, di mana hak-hak untuk hidup, hak kebebasan beragama, hak untuk memperoleh 


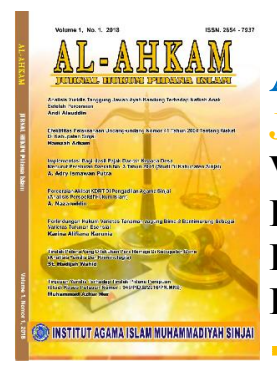

Al-Ahkam

Jurnal Hukum Pidana Islam

Volume 2, No. 2, 2020

ISSN (print) : 2654-7937

ISSN (online) : 2715-0313

Homepage : http://journal.iaimsinjai.ac.id/index.php/al-ahkam/index

pekerjaan, hak untuk memperoleh penghidupan yang layak, hak untuk meperoleh pendidikan, hak keadilan, hak kemerdekaan, hak berkomunikasi, hak keamanan dan hak kesejahteraan adalah hak yang tidak dapat dirampas oleh siapa pun.

Perlindungan anak merupakan suatu tindakan hukum yang berakibat hukum. Oleh karena itu, perlu adanya jaminan hukum bagi perlindungan anak. Kepastian hukum perlu diusahakan demi kelangsungan perlindungan anak dan mencegah penyelewengan yang membawa akibat negatif yang tidak diingingkan dalam pelaksanaan kegiatan perlindungan anak.

Anak dalam Undang-Undang Sistem Peradilan Pidana Anak dalam pasal 1 ayat 3 disebutkan bahwa anak yang berkonflik dengan hokum adalah anak yang telah berusia 12 (Dua Belas) tahun, tetapi belum berumur 18 (Delapan Belas) tahun yang diduga melakukan tindak pidana. Masalah anak melakukan tindak pidana mudah dipahami, yakni melanggar ketentuan dalam peraturan hokum pidana yang ada. Misalnya melanggar pasal-pasal yang diatur dalam KUHP atau peraturan hokum pidana lainnya yang tersebar diluar KUHP. Sedangkan pasal 1 ayat 2 menyebutkan bahwa disamping anak yang berkonflik dengan hokum juga anak yang menjadi korban tindak pidana (anak saksi). Baik anak yang berkonflik dengan hokum, anak korban dan anak saksi disebut anak yang berhadapan dengan hokum.

Dalam penjelasan umum menyebutkan bahwa sistem peradilan anak bermaksud untuk menghindari dan menjauhkan anak dari proses peradilan, berupa kewajiban mengutamakan pendekatan keadilan restorative merupakan suatu proses Diversi baik terhadap pelaku maupun terhadap korban.

Undang-Undang Sistem Pradilan Pidana Anak, secara tegas disebut dalam Pasal 5 ayat 3 bahwa dalam sistem peradilan pidana anak wajib diupayakan diversi. Tetapi, dalam Pasal 7 ayat 2 terdapat pembatasan mengenai tindak pidana yang boleh dilaksanakannya diversi yaitu diancam dengan pidana penjara di bawah 7 tahun dan bukan merupakan pengulangan tindak pidana.

Adapun anak yang melakukan tindak pidana di atas 7 tahun dan pengulangan tindak pidana. Negara Indonesia adalah negara Hukum dan semua anak berhak tumbuh dan berkembang yang dalam pemenuhannya tidak boleh dibeda-bedakan. Dari latar belakang tersebut diatas penulis ingin mengambil suatu penelitian dengan judul “ Implementasi Sistem Pembaruan Peradilan Pidana Pada Anak Di Kabupaten Sinjai”.

\section{Metode}

Dalam peneltian ini penulis menggunakan metode pendekatan Empiris yang dilaksanakan pada tahun 2020 berlokasi di kabupaten Sinjai Provinsi Sulawesi Selatan, dengan sasaran anak yang menjadi korban atau pelaku suatu tindak pidana, subjek penelitian yaitu kasus diversi anak di bawah umur sebagai pelaku tindak pidana di Pengadilan Negeri Sinjai, data diperoleh dari kantor Pengadilan Negeri Sinjai dengan teknik Wawancara dan Dokumentasi. Adapun teknik analisis data menggunakan 4 langkah yaitu 1. Pengumpulan data (Mengolah dan mempersiapkan data untuk dianalisis), 2. Reduksi data (menggolongkan, mengarahkan, membuang yang tak perlu dan mengorganisasikan data-data yang telah di reduksi memberikan gambaran yang lebih tajam tentang hasil pengamatan menjadi tema), 3. Penyajian Data (analisis data dalam bentuk matrik, network, cart, atau grafis), 4. Penarikan Kesimpulan (Kesimpulan awal yang dikemukakan masih bersifat sementara, dan akan berubah apabila tidak ditemukan bukti-bukti kuat yang mendukung tahap pengumpulan berikutnya). 


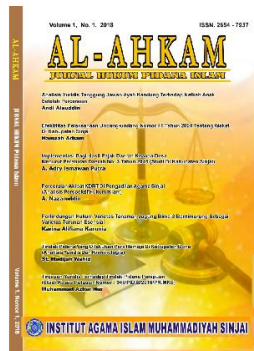

\section{Hasil dan Pembahasan}

\subsection{Implementasi Putusan Nomor Perkara 2/Pen.Div/2020 Pengadilan Negeri Sinjai terhadap proses perkara anak sebagai pelaku tindak pidana}

Pengadilan Negeri Sinjai sudah ada sejak zaman penjajahan Belanda. Pada zaman itu Pengadilan Negeri Sinjai masih dikenal dengan nama Landrat, dan dipimpin seorang ketua yang dikenal dengan Tuan Petoro. Setelah Indonesia Merdeka, sejak tahun 1960an barulah Landrat berubah nama menjadi Pengadilan Negeri Ekonomi. Pada saat 1982 peresmian Pengadilan Negeri Sinjai yang Diresmikan Oleh Dirjen Kemenkunham SulSelRa dan peresmian gedung baru yang beralamat di jl. Jenderal Sudirman No. 1 Sinjai.

Lokasi Pengadilan Negeri Kabupaten Sinjai terletak di kabupaten sinjai, Sulawesi selatan, di jalan jenderal Sudirman No 2, Balangnipa, Sinjai Utara, luas wilayah 819,96 km2 atau 81.996 ha.. Secara Geografis Sinjai terletak pada titik 502'56"- 5021'16"' lintang selatan dan 119056'30''-120025'33' bujur timur.

Secara Yuridiksi, wilayah Pengadilan Negeri Sinjai mencakup 9 (sembilan) kecamatan, 13 kelurahan dan 67 desa, yaitu:

1. Kecamatan Sinjai Utara, 6 kelurahan

2. Kecamatan Sinjai Timur, 1 kelurahan dan 12 desa

3. Kecamatan Sinjai Tengah, 1 kelurahan dan 10 desa

4. Kecamatan Sinjai Barat, 2 kelurahan dan 7 desa

5. Kecamatan Sinjai Selatan, 1 kelurahan dan 10 desa

6. Kecamatan Sinjai Borong, 1 kelurahan dan 7 desa

7. Kecamatan Bulupoddo, 7 desa

8. Kecamatan Tellu Limpoe, 1 kelurahan dan 10 desa

9. Kecamatan Pulau Sembilan, 4 desa yang merupakan wilayah kepulauan

Hukum pidana modern menyatakan bahwa pemidanaan yang diterima oleh seorang anak yang melakukan perbuatan itu tidak hanya berupa pidana, akan tetapi juga tindakan yang bertujuan untuk melindungi masyarakat dari perbuatan-perbuatan yang merugikannya yang sering disebut dengan double track system, namun dilihat dari latar belakang kemunculan dapat disimpulkan bahwa ide dasar sistem tersebut adalah kesetaraan antara sanksi pidana dan sanksi tindakan.

Dalam hal penjatuhan sanksi pidana pada anak yang berhadapan dengan hukum, ternyata terdapat beberapa aspek yang perlu diperhatikan dalam penjatuhan sanksi pidana. Hal ini mengandung maksud bahwa dalam hal penjatuhan sanksi pidana, walaupun substansi dan pemenuhan unsur sama dengan orang dewasa namun pengenaan sanksi pidananya tidak sama dengan orang dewasa.

Berkaitan dengan perumusan suatu norma atau peraturan perundang- undangan maka dalam hal ini norma hukum ditetapkan oleh badan hukum yang berwenang. Sistem peradilan pidana anak (juvenile justice system) adalah segala unsur sistem peradilan pidana yang terkait di dalam penanganan anak yang bermasalah dengan hokum

Perlindungan hukum terhadap anak dalam proses peradilan dilakukan dimulai semenjak tingkat penyelidikan, penyidikan, penuntutan, pemeriksaan di sidang pengadilan sampai pada pelaksanaan putusan pengadilan, selama proses peradilan tersebut, maka hak-hak anak wajib dilindungi oleh hukum yang berlaku dan oleh sebab itu harus dilakukan secara konsekuen oleh pihak-pihak terkait dengan penyelesaian masalah anak tersebut.

Adapun hal-hal yang harus diperhatikan dalam proses penanganan anak yang berhadapan dengan hukum adalah sebagai berikut : 


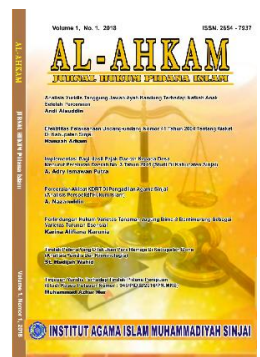

\section{Al-Ahkam}

Jurnal Hukum Pidana Islam

Volume 2, No. 2, 2020

ISSN (print) : 2654-7937

ISSN (online) : 2715-0313

Homepage : http://journal.iaimsinjai.ac.id/index.php/al-ahkam/index

1. Proses Penyidikan, Penyidikan itu sendiri, berarti serangkaian tindakan penyidik, dalam hal dan menurut cara yang diatur dalam undang-undang ini untuk mencari dan mengumpulkan bukti yang dengan bukti itu membuat terang tentang tindak pidana yang terjadi dan guna menemukan tersangkanya.

Penyidikan terhadap anak yang berhadapan dengan hukum dilakukan oleh penyidik anak yang ditetapkan berdasarkan Surat Keputusan Kepala Kepolisian RI atau pejabat yang ditunjuknya, dimana berdasarkan Pasal 41 ayat (2) yang berbunyi :

Syarat-syarat untuk dapat ditetapkan sebagai Penyidik sebagaimana dimaksud dalam ayat (1) adalah :

a. Telah berpengalaman sebagai penyidik tindak pidana yang dilakukan oleh orang dewasa;

b. Mempunyai minat, perhatian, dedikasi, dan memahami masalah anak,

Sedangkan terkait dengan penyidikan anak tersebut haruslah dalam suasana kekeluargaan sebagaimana diatur dalam Pasal 42 Ayat (1), (2) dan (3) Undang-Undang Republik Indonesia Nomor 3 Tahun 1997 Tentang Pengadilan Anak menyebutkan bahwa :

a. Penyidik wajib memeriksa tersangka dalam suasana kekeluargaan;

b. Dalam melakukan penyelidikan terhadap anak nakal, penyidik wajib meminta pertimbangan atau saran dari pembimbing kemasyarakatan, dan apabila perlu juga dapat meminta pertimbangan atau saran dari ahli pendidikan, ahli kesehatan jiwa, ahli agama, atau petugas kemasyarakatan lainnya;

c. Proses penyidikan terhadap anak nakal wajib dirahasiakan

Bertolak dari hal tersebut maka pada waktu pemeriksaan terhadap anak yang berhadapan dengan hukum tersebut seorang penyidik tidak memakai seragam atau dinas dan melakukan pendekatan secara efektif, aktif, dan simpatik

2. Proses Penahanan

Penahanan Anak harus memperhatikan kepentingan yang menyangkut pertumbuhan dan perkembangan anak baik fisik, mental, maupun sosial anak serta mempertimbangkan kepentingan masyarakat misalnya dengan ditahannya anak akan membuat masyarakat aman dan tenteram.

Adapun penahanan tahap pertama terhadap anak juga sama dengan penahanan terhadap orang dewasa yaitu dilakukan hanya berlaku paling lama 20 (dua puluh) hari dan apabila belum selesai, atas permintaan penyidik dapat diperpanjang oleh penuntut umum yang berwenang untuk paling lama 10 (sepuluh) hari. Dalam waktu 30 (tiga puluh hari), Polri sebagai penyidik tindak pidana sudah harus menyerahkan berkas perkara yang bersangkutan kepada Penuntut Umum, apabila jangka waktu tersebut dilampaui dan berkas perkara belum diserahkan maka tersangka harus dikeluarkan dari tahanan demi hukum. Perbedaan antara penahanan terhadap anak dengan penahanan orang dewasa terletak di jangka waktu perpanjangan penahanan apabila proses penyidikan belum selesai. Jika anak-anak diperpanjang paling lama 10 (sepuluh) hari tapi jika orang dewasa dapat diperpanjang paling lama 40 (empat puluh) hari. Di samping itu penahanan terhadap anak dilaksanakan di tempat khusus untuk anak di 


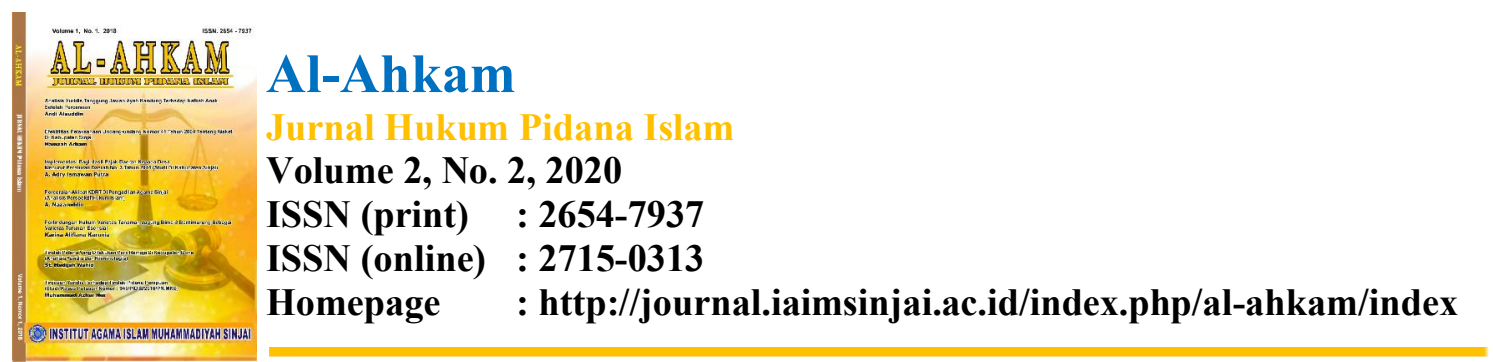

lingkungan Rumah Tahanan Negara, Cabang Rumah Tahanan Negara atau di tempat tertentu.

3. Proses Penuntutan

Proses penuntutan dipandang sangat diperlukan untuk mendapatkan perlindungan hukum terkait dengan hak-hak anak dalam proses penuntutan meliputi :

a. Menetapkan masa tahanan terhadap anak cuma pada sudut urgensi pemeriksaan.

b. Membuat dakwaan yang dimengerti oleh anak

c. Secepatnya melimpahkan pada Pengadilan Negeri

d. Melaksanakan penetapan hakim dengan jiwa dan semangat pembinaan atau mengadakan rehabilitasi.

4. Proses Persidangan

Penanganan anak dalam proses hukumnya memerlukan pendekatan, pelayanan, perlakuan, perawatan serta perlindungan yang khusus dalam upaya memberikan perlindungan hukum terhadap anak yang berhadapan dengan hukum. Perlindungan hukum anak yang berhadapan dengan hukum kedudukannya sangat penting mengingat dalam mekanisme prosesnya hal terkait dengan perlindungan anak tidak boleh diabaikan.

proses peradilan pidana anak harus menggambarkan adanya jaminan-jaminan khusus bagi anak di bidang anak yang berhadapan dengan hukum.

Masalah proses penanganan terhadap anak yang bermasalah dengan hukum dalam hal ini perlu untuk sangat diperhatikan terkait dengan masalah sumber daya manusia (SDM) dari aparat penegak hukum khususnya dari sub-sistem kepolisian, dimana dalam The Beijing Rules dalam Rule 12.1 menekankan adanya suatu pendidikan khusus dan latihan khusus bagi aparat penegak hukum khususnya kepolisian sehingga dalam hal ini unit polisi khusus yang terdidik dan terlatih menangani proses penanganan anak yang bermasalah dengan hukum.

5. Proses Pelaksanaan Pidana

Pembinaan atau bimbingan merupakan sarana yang mendukung keberhasilan negara menjadikan narapidana menjadi anggota masyarakat. Lembaga pemasyarakatan berperan dalam pembinaan narapidana, yang memperlakukan narapidana agar menjadi baik, yang perlu dibina adalah pribadi narapidana, membangkitkan rasa harga diri dan mengembangkan rasa tanggungjawab untuk menyesuaikan diri dengan kehidupan yang tenteram dan sejahtera dalam masyarakat, sehingga berpotensi menjadi manusia yang berpribadi dan bermoral tinggi.

Pembinaan mental dilakukan mengingat terpidana mempunyai masalah seperti perasaan bersalah, merasa diatur, kurang biasa mengontrol emosi, merasa rendah diri yang diharapkan secara bertahap mempunyai keseimbangan emosi.

Telah diuraikan sebelumnya bahwa anak yang berhadapan dengan hukum berhak tumbuh dan berkembang yang dalam pemenuhannya tidak boleh dibedabedakan, hal tersebut sesuai tujuan dari peradilan anak yaitu untuk menghindari dan menjauhkan anak dari proses peradilan.

Diberikannya pertimbangan bilamana layak untuk menangani pelanggar hokum yang berusia muda tanpa menggunakan peradilan formal oleh pihak berwenang yang berkompoten. 
Diversi apapun yang melibatkan perujukan kepada pelayanan masyarakat atau pelayanan lain memerlukan persetujuan anak, orang tua atau walinya dengan syarat keputusan merujuk perkara dan bergantung pada kajian pihak berwenang yang berkompeten atas permohonan.

Salah satu kasus perkara anak sebagai pelaku tindak pidana yang di proses pada Pengadilan Negeri Sinjai dengan Putusan Nomor Perkara 2/Pen.Div/2020 sebagai berikut :

Penganiayaan yang dilakukan oleh Arman Bin Adnan, Umur : 16 (Enam Belas) Tahun, Alamat : Dusun Balangpesoang Rilau, Kel. Samaturue, Kec. Tellulimpoe, Kab. Sinjai, terhadap korban Ardi Kurniawan Bin Abd. Latif, Umur 15 (Lima Belas) Tahun, Alamat : Dusun Jatie, Desa Samaturue, Kec. Tellulimpoe, Kab. Sinjai. Terjadi ketika pelaku datang disekitar rumah korban dan makan buah langsat. Setelah selesai, pelaku mendatangi rumah korban dan mengambil memory Handphone tanpa sepengetahuan korban. Setelah kejadian tesebut, korban menelepon pelaku untuk menanyakan tentang keberadaan memory Handphone, kemudian pelaku mengiyakan bahwa benar pelaku yang mengambil memory Handphone tersebut. kemudian korban meminta untuk dikembalikan karena mau digunakan, lalu pelaku menjawab ia nanti saya kembalikan. setelah 3 hari memori tidak juga di kembalikan, maka korban menelpon lagi pelaku dan bertaya di mana memoriku, pelaku menjawab tidak ada hilang, pada saat itu korban mengatakan kepada pelaku Pencuri Memori, setelah itu pelaku mengancam dan mengatakan perkataan yang tidak senonoh.

Pelaku mengakui bahwa memory Hp digunakan, karena dipinjamkan oleh korban, kemudian pelaku meminjamkan juga memory tersebut ke kakaknya setelah itu korban mengucapkan perkataan bahwa pelaku adalah seorang pencuri memory karena belum dikembalikan, setelah mendengar ucapan tersebut barulah pelaku kemudian mengembalikan memory tersebut namun tidak secara lansung kepada korban tapi dititipkan kepada adik kandung korban. Setelah memory dikembalikan, korban masih tetap mengatakan bahwa pelaku adalah seorang pencuri.

Adapun latar belakang terjadinya penganiayaan yaitu karena korban menuduh pelaku sebagai pencuri memory HP dalam kolom komentar media sosial Facebook, selain itu korban juga bercerita kepada warga setempat dan teman-temannya bahwa pelaku adalah seorang pencuri memory Hp, sehingga pelaku Arman Bin Adnan merasa keberatan karna merasa diinjak-injak harga dirinya atas tuduhan korban tersebut sehingga korban melakukan Tindakan penganiayaan bersama dengan teman-temannya.

Pada hari senin tanggal 07 Oktober 2019 sekitar pukul 11.30 wita. awal mula kejadian pada hari itu pelaku Arman ke bengkel untuk ganti oli motor, setelah ganti oli motor pelaku Arman menghampiri temannya Muh Nishar Akmal Jaya dan Faisal di warkop. Setelah itu mereka bersama-sama mendatangi lokasi korban berada, dimana pada saat itu korban berada di Lingkungan Sekolah SMP 2 Sinjai, Kel. Sangiaseri, Kec. Sinjai selatan, Kab. Sinjai. Setelah pelaku berada di depan sekolah korban, pelaku Arman dan pelaku Muh Nishar Akmal Jaya dan pelaku Faisal masuk di dalam lingkugan sekolah lewat pagar sekolah karena pintu masuk dijaga oleh satpam. Setelah berada di dalam lingkungan sekolah pelaku Muh Nishar Akmal Jaya berdiri di depan kelas korban. Sehingga dengan itu korban beralasan untuk ke Wc untuk buang air kecil, namun pada saat itu korban tidak ke wc, justru korban langsung menuju kepelaku yang berada di belakang 


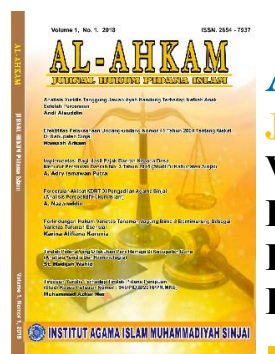

Al-Ahkam

Jurnal Hukum Pidana Islam

Volume 2, No. 2, 2020

ISSN (print) : 2654-7937

ISSN (online) : 2715-0313

Homepage : http://journal.iaimsinjai.ac.id/index.php/al-ahkam/index

kelas. Pada saat itu korban melompoti pelaku Muh Nishar Akmal Jaya dan memukulnya di bagian muka sampai berdarah. Dengan itu pelaku Arman memukul korban dari arah belakang di bagian kepala. Kemudian menarik korban, pelaku Muh Nishar Akmal Jaya memukul muka korban dari arah depan dan memukul dada korban. Setelah itu salah satu guru sekolah datang dan pelaku Arman dan pelaku Muh Nishar Akmal Jaya dan Faisal lari melompati pagar, tapi pada saat itu korban masih sempat mengambil batu merah dan melempar ke arah Muh Nishar Akmal Jaya. Setelah itu korban pinsang, korban sadar pada saat berada di Puskesmas Bikeru. Tidak lama pada saat itu orang tua korban mengetahui akan kejadian tersebut sehingga ia merasa keberatan dan melaporkan kejadian tersebut ke kantor polisi.

Dari kejadian tersebut, korban mengalami benjol pada bagian kepala samping kiri ukuran 12 (Dua Belas) cm, Nampak kemerahan pada lengan kiri.

Berdasarkan perbuatan pelaku tersebut diatas, secara yuridis telah melanggar hukum sebagaimana dimaksud dalam Pasal 80 Ayat 1 Jo 76 C Undang-Undang Republik Indonesi Nomor 17 Tahun 2016 Tentang Penetapan Peraturan Pemerintah Penganti Undang-Undang Nomor 17 Tahun 2006 Tentang Perubahan Kedua Atas Undang-Undang Nomor 23 Tahun 2002 Tentang Perlindungan Anak Sub Pasal 170 KUH Pidana.

Setelah dilakukannya persidangan terhadap pelaku maka pengadilan negeri sinjai melakukan penetapan Diversi terhadap perkara Nomor 2/Pen.Div/2020 PN Snj dengan pertimbangan :

a. Berdasarkan musyawarah Bersama pelaku ninta maaf kepada pihak korban atas segalah perbuatan yang telah melakukan penganiayaan dan berjanji tidak akan mengulangi lagi perbuatanya baik terhadap korban mau pun kepada pihak lain dalam bentuk pelanggaran apa pun.

b. Bahwa orang tua tersangkah (anak pelaku bersedia melakukan pembinaan agar tidak pengulangi lagi perbuatanya.

c. Bahwa pihak korban bersediah memafkan pelaku dan menyetujui agar pelaku di kembalikan kepada keluargannya untuk di lakukan untuk di lakukan pembinaan dengan persyaratan pihak anak pelaku memberikan ganti rugi berupa uang tunai sebesar Rp. 500.00 (lima ratus ribu rupiah).

d. Masing-masing pihak sepakat agar perkara tersebut diselesaikan secara diversi dan penyelesaian secara adil yang melibatkan anak pelaku, korban orang tua anak, pelaku dan pihak-pihak yang terkait dengan perkara (keadilan restoratif).

e. Pihak pelopor/korban setuju untuk tidak meneruskan proses penyelidikan pidana terhadap terlapor.

f. Kesepakatan ini dibuat dan ditanda-tangani oleh pihak-pihak tanpa ada unsur paksaan serta tekanan dari pihak manapun dengan dihadiri oleh anak pelaku pelaku orang tua/wali. Pembimbing kemasyarakatan dan fasilitator diversi.

Pertimbangan di atas menjadi alasan hakim memberikan penetapan, bahwa kesepakatan diversi tersebut telah memenuhi dan tidak bertentangan dengan hukum, agama, kepatuhan masyarakat setempat, kesusilaan atau memuat hal-hal yang tidak dapat dilaksanakan anak, dan telah memuat etika baik, sehingga beralasan untuk dikabulkan.

Penetapan nomor Perkara 2/Pen. Div/2020 PN Snj. hasil kesepakatan diversi yang dilakukan pada tanggal 3 Desember 2019. Berdasarkan UndangUndang Nomor 11 Tahun 20012 Tentang Sistem Perlindungan Pidana Anak. 


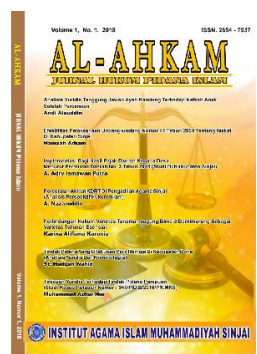

Al-Ahkam

Jurnall Hukum Pidana Islam

Volume 2, No. 2, 2020

ISSN (print) : 2654-7937

ISSN (online) : 2715-0313

Homepage : http://journal.iaimsinjai.ac.id/index.php/al-ahkam/index

pelaksanaan diversi ini harus dilakukan pada tingkat penyidikan, penuntutan, dan pemeriksaan perkara anak di pengadilan negeri wajib diupayakan diversi.

Hakim menimbang bahwa kesepakatan diversi tersebut telah memenuhi syarat dan tidak bertentangan dengan hukum, agama, kepatuhan masyarakat setempat, kesusilaan atau membuat hal-hal yang tidak dapat dilaksanakan anak, telah memuat etika baik, sehingga beralasan untuk dikembalikan.

\subsection{Dampak Putusan Pengadilan Negeri Sinjai terhadap anak yang sementara menjalani putusan pengadilan}

Pengadilan anak dimaksudkan untuk menanggulangi keadaan yang kurang menguntungkan bagi anak-anak, dan dalam pelaksanaan proses peradilan pidana anak tidak boleh diperlakukan sama seperti orang dewasa. dalam rangka mewujudkan suatu peradilan yang benar- benar memperhatikan kepentingan anak perlu diwujudkan peradilan yang terbatas bagi anak untuk menjamin kepentingan anak.

Seringkali anak yang berhadapan dengan hokum menerima perlakuan buruk dari masyarakat sehingga akan memepengaruhi kondisi kejiwaan anak. Segala tindakan yang dilakukan seorang anak karena kemauannya, tidak dilandasi oleh faktor tunggal terjadinya kejahatan, namun karena adanya factor lain yang melatar belakangi, diantaranya kondisi lingkungan, ekonomi, dll. Hal tersebut menjadikan anak sebagai pelaku kejahatan berada dalam posisi sebagai korban.

Secara umum, anak yang berada dalam posisi berhadapan dengan hokum yang sementara menjalani putusan pengadilan memperoleh pengaruh yang buruk dapat berupa:

a. Trauma akibat perlakuan aparat penegak hukum pada setiap tahapan

b. Stigma atau cap jahat pada diri sipelaku sehingga anak tersebut selalu dikhawatirkan akan berbuat jahat;

c. Anak dikeluarkan dari sekolah.

Penetapan nomor Perkara 2/Pen. Div/2020 PN Snj. hasil kesepakatan diversi dalam peyelesaian kasus pelaku Arman berdasarkan Undang-Undang Nomor 11 Tahun 2012 Tentang Sistem Perlindungan Pidana Anak, secara umum tidak dapat menghapus pengaruh buruk yang deperoleh anak. Untuk itu dibutuhkannya Asas kepentingan terbaik buat anak, dalam semua tindakan yang menyangkut anak, baik yang dilakukan oleh lembaga-lembaga kesejahteraan sosial pemerintah atau swasta, lembaga pengadilan, lembaga pemerintah atau badan legislatif, kepentingan terbaik buat anak harus dijadikan pertimbangan utama. Penyelesaian pidana anak pelaku tindak pidana telah di lakukan dengan pendekatan restoratif justice atau keadilan restoratif adalah penyelesaian perkara tindak pidana dengan melibatkan pelaku, korban, keluarga pelaku/korban, dan pihak lain yang terkait untuk bersama-sama mencari penyelesaian yang adil dengan menekankan pemulihan kembali pada keadaan semula, dan bukan pembalasan perbuatan

\section{Simpulan}

Implementasi Putusan Nomor Perkara 2/Pen.Div/2020 Pengadilan Negeri Sinjai pada peradilan anak di Kabupaten Sinjai merupakan sebuah contoh kasus yang telah melindungi hak-hak anak yang sedang berhadapan dengan hukum dimana telah di upayakannya Diversi dalam setiap tingkat pemeriksan, penyelidikan, tuntutan, dan persidangan sehingga penerapan diversi yang di lakukan dengan tujuan agar dapat terwujud peradilan yang dapat menjamin perlindungan kepentingan terbaik terhadap anak yang berhadapan dengan hukum sebagai penerus bangsa.

Perkara anak sebagai pelaku tindak pidana yang di proses pada Pengadilan Negeri Sinjai dengan Putusan Nomor Perkara 2/Pen.Div/2020 dapat menimbulkan pengaruh 


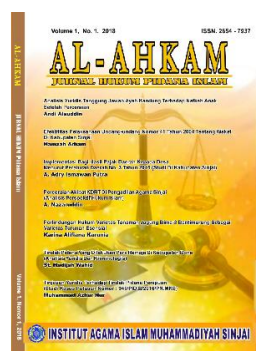

buruk bagi anak dimana hal tersebut dapat menjadikan anak pelaku tindak pidana berada dalam posisi sebagai korban sehingga dapat mengancam masa depan anak.

\section{Daftar Pustaka}

Abintoro Prakoso (2016). Pembaruan Sistem Peradilan Pidana Anak. Sleman, Yogyakarta: Aswaja Pressindo

Konvensi Hak-Hak Anak, Perserikatan Bangsa-Bangsa, Bagian 1 Pasal 3, ayat 1.

Agung Nugroho, (Sinjai tanggal 3 januari 2020). Ketua Pengadilan Negeri Sinjai Kelas II, penetapan nomor Perkara 2 / Pen. Div / 2020 PN Snj..

Republik Indonesia, Undang-Undang Nomor 11 Tahun 2012 Tentang Sistem Perlindungan Pidana Anak, BAB II, Pasal 7, Ayat 2.

Andi Devi Yusriana, (2013). Penerapan Hukum Acara Pengadilan Anak Sebagai Pelaku Tindak Pidana, Makassar: Program Pascasarjana Universitas Hasanuddin Makassar.

Laurensium Arliman S, (2015). Komnas Ham Dan Perlindungan Anak Pelaku Tindak Pidana, Cet, I; Yogyakarta: CV Budi Utama.

Liza angnesta krisna, (2016). Hukum Perlindungan Anak: Panduan Anak Yang Berkonflik Dengan Hukum, Cet, I; Yogyakarta: Deepublesh. 